\title{
Cross-cultural psychopharmacology: a review
}

\author{
Edmond $\mathrm{HPi}^{*}$, Weiguo Zhu \\ From $1^{\text {st }}$ International Congress on Neurobiology and Clinical Psychopharmacology \\ and European Psychiatric Association Conference on Treatment Guidance \\ Thessaloniki, Greece. 19-22 November 2009
}

Cross-cultural psychopharmacology seeks to determine whether there are differences in responses to psychopharmacologic agents among various ethnic groups and the reason for such variations. During the past four decades numerous clinical reports have addressed potential differences in therapeutic dosages and side effects of psychotropic medications between various ethnic groups. In addition, several rigorously designed studies have focused on ethnic differences in pharmacokinetics (including absorption, metabolism, distribution and excretion) and pharmacodynamics (including receptor-coupling activity). These ethnic variations are mainly influenced by genetic predisposition but are also influenced by other factors such as culture, environment, psychosocial supports, and attitudes towards pharmacology.

This presentation will provide a critical review of the existing information in regard to psychotropic medications including neuroleptics, antidepressants, lithium, and benzodiazepines among various ethnic groups. Also included will be data on neuroleptic-induced movement disorders, the clinical implications of genetic polymorphism of cytochrome P-450 isoenzymes, recommendations on how to better design a pharmacological approach in the treatment of psychiatric disorders among different ethnic groups, as well as recent advances and future directions regarding cross-cultural issues of psychopharmacology.
Published: 22 April 2010

References

1. Pi EH, Zhu WG: New Research Advances in Ethnopsychopharmacology: An Asian Perspective. Journal of International Psychiatry 2007, 4:57-58.

2. Pi EH, Gray GE: A Cross-cultural Perspective on Psychopharmacology. Essential Psychopharmacology 1998, 2:233-262.

doi:10.1186/1744-859X-9-S1-S82

Cite this article as: $\mathrm{Pi}$ and Zhu: Cross-cultural psychopharmacology: a review. Annals of General Psychiatry 2010 9(Suppl 1):S82.
Submit your next manuscript to BioMed Central and take full advantage of:

- Convenient online submission

- Thorough peer review

- No space constraints or color figure charges

- Immediate publication on acceptance

- Inclusion in PubMed, CAS, Scopus and Google Scholar

- Research which is freely available for redistribution

Submit your manuscript at www.biomedcentral.com/submit
C Biomed Central 